\title{
MEMBANGUN KEPERCAYAAN KONSUMEN DARI KUALITAS PELAYANAN DAN KEMITRAAN DALAM MEMILIH JASA KONSULTAN LINGKUNGAN HIDUP DI PROPINSI BANTEN
}

\author{
Kasmad $^{\star}$, Juhaeri $\left.{ }^{\star \star}\right)$ \\ dosen00559@unpam.ac.id
}

\begin{abstract}
ABSTRAK
MEMBANGUN KEPERCAYAAN KONSUMEN DARI KUALITAS PELAYANAN DAN KEMITRAAN DALAM MEMILIH JASA KONSULTAN LINGKUNGAN HIDUP DI PROPINSI BANTEN. Tujuan penelitian ini adalah untuk mengetahui seberapa besar kepercayaan konsumen dapat dipengaruhi oleh kualitas pelayanan dan kemitraan dalam memilih jasa konsultan lingkungan hidup di propinsi Banten. Metode yang digunakan dalam penelitian ini adalah metode kuantitatif, Analisis yang digunakan dengan uji Validitas, Reliabilitas, Uji Asumsi Klasik dan Uji Linieritas. Adapun hasil penenlitian menunjukan bahwa seluruh instrument yang digunakan telah diuji validitas dan hasilnya valid, semua variabel telah lakukan uji reliabilitas dengan hasil perhitungan semua variabel reliabel. Hasil analisis regresi parsial menunjukkan bahwa kualitas pelayanan berpengaruh signifikan terhadap kepercayaan konsumen dengan nilai prediksi (regresi) sebesar 0.388, nilai thitung sebesar 3.544 dan nilai signifikansi sebesar 0.001 , kemitraan berpengaruh signifikan terhadap kepercayaan konsumen dengan nilai prediksi (regresi) sebesar 0.467 , nilai $t_{\text {hitung }}$ sebesar 4.020 dan nilai signifikansi sebesar 0.000 , kualitas pelayanan dan kemitraan secara bersama-sama berpengaruh signifikan terhadap kepercayaan konsumen dengan nilai kontribusi sebesar 0.602 , nilai $F_{\text {hitung }}$ sebesar 65.362 dan nilai signifikansi sebesar 0.000 .
\end{abstract}

Kata Kunci : Kepercayaan Konsumen, Kualitas Pelayanan dan Kemitraan.

\begin{abstract}
BUILDING CONSUMER TRUST FROM THE QUALITY OF SERVICE AND PARTNERSHIP IN CHOOSING ENVIRONMENTAL CONSULTANT SERVICES IN BANTEN PROVINCE. The purpose of this research is to find out how much consumer trust can be influenced by the quality of service and partnership in choosing environmental consulting services in Banten Province. The method used in this study is a quantitative method, the analysis used with the Validity, Reliability, Classic Assumption Test and Linearity Test. The results of the study show that all instruments used have been tested for validity and the results are valid, all variables have been tested for reliability with the results of calculating all reliable variables. The results of partial regression analysis show that the quality of service has a significant effect on consumer confidence with a predictive value (regression) of 0.388 , a value of $t$ count of 3.544 and a significance value of 0.001 , the partnership has a significant effect on consumer confidence with a predictive value of 0.467 , tcount of 4,020 and a significance value of 0,000 , the quality of service and partnership together have a significant effect on consumer confidence with a contribution value of 0.602 , the Fcount value is 65,362 and a significance value of 0,000.
\end{abstract}

Keywords : Consumer Trust, Service Quality and Partnership.

${ }^{*}$ ) dan ${ }^{* *}$ ) Dosen Program Studi Magister Manajemen - Unpam 
JURNAL ILMIAH ILMU MANAJEMEN

\section{PENDAHULUAN}

\section{A. Latar Belakang}

Lingkungan hidup merupakan tempat atau ruang didalam satu kesatuan dengan semua benda, keadaan, daya, serta makhluk hidup, termasuk manusia serta perilakunya, yang mempengaruhi alam itu sendiri, kelangsungan hidup, dan kesejahteraan manusia dan makhluk hidup lain. Dengan kata lain linkungan hidup merupakan semua benda, daya, keadaan, dan kondisi suatu tempat manusia itu berada dan dapat mempengaruhi satu sama lain.

Dari penjelasan diatas, dapat disimpulkan bahwa wajib bagi semua organisasi maupun perusahan dalam setiap kegiatan pembangunan untuk memperhatikan llinkungan hidup dan masyarakat sekitar. Oleh sebab itu didalam proses AMDAL, organisasi atau perusahaan harus menjamin suatu kegiatan atau usaha pembangunan layak secara lingkungan serta sesuai peruntukannya yang tidak menyebabkan kerusakan sumber daya alam seperti : air, tanah, dan udara, serta tidak menyebabkan punahnya hewan dan mengancam keselamatan, kenyamanan, keamanan serta kesehatan kehidupan manusia sekitar.

Dalam proses pengurusan AMDAL, umumnya pemrakarsa dalam hal ini perusahaan yang berkepentingan secara paket menyerahkan kepada perusahaan konstruksi sebagai kontraktor yang mengerjakan proyek dari pemrakarsa. Mengingat kegiatan pengerjaan konstruksi satu paket dengan AMDAL, maka orang atau lembaga yang dianggap bisa dan biasa dalam mengurus AMDAL adalah perusahaan konstruksi, dan dengan alasan itu pemrakarsa melimpahkan seluruh proses pengerjaan konstruksi kepada perusahaan konstruksi, mulai dari pengurusan AMDAL, izin lingkungan, pengerjaan proyek hingga finalisasi proyek.

Kondisi ini menggambarkan bahwa ada peluang yang menarik bagi para konsultan penyedia jasa lingkungan untuk mendapatkan kepercayaan dari para perusahaan yang menjeadi konsumennya atau biasa di sebut Business to Business /B2B. Dikarenakan bahwa perusahaan dalam hal ini merupakan salah satu konsumen yang sangat selektif dalam memilih jasa konsultan linkungan dan ditambah dengan banyaknya pesaing dengan jasa konsultan lain yang sudah lama berdiri dengan pengalamannya. Permasalahan AMDAL di era globalisasi saat ini semakin konfrehensip, oleh karena itu dibutuhkan tenaga ahli atau orang-orang yang berpengalaman dan kompeten sehingga kedepan tidak akan menimbulkan permasalahan yang akan merugikan pihak perusahaan. Dalam hal pengurusan izin AMDAL biasanya banyak pihak yang terlibat, apalagi kalau nilai investasinya besar sudah barang tentu banyak yang bermain. Perusahaan sebagai konsumen kepingin semuanya lancer dan berjalan dengan baik, tetapi mereka hanya terima beres tanpa terlibat berbagai masalah di lapangan maupun dimasa yang akan datang. Oleh sebab itu sebagai jasa konsultan lingkungan harus professional dan cerdas dalam menjalankan usahanya agar terbangun kepercayaan dari konsumen, sehingga akan banyak persahaan yang akan menjadi kliennya. 


\section{B. Identifikasi Masalah}

Banyak faktor yang mempengaruhi kepercayaan konsumen, di antaranya kualitas pelayanan dan kemitraan serta faktor lain di luar penelitian ini, misalnya kepuasan, loyalitas, komitmen, word of mouth dan jaringan pemasaran.

\section{Perumusan Masalah}

Dari uraian penjelasan diatas dapat disampaikan rumusan masalah sebagai berikut:

1. Apakah terdapat pengaruh kualitas pelayanan terhadap kepercayaan konsumen dalam menggunakanJasa Konsultan Lingkungan di Provinsi Banten ?

2. Apakah terdapat pengaruh kemitraan terhadap kepercayaan konsumen dalam menggunakanJasa Konsultan Lingkungan di Provinsi Banten?

3. Apakah terdapat pengaruh kualitas pelayanan dan kemitraan secara bersama-sama terhadap kepercayaan konsumen dalam menggunakan Jasa Konsultan Lingkungan di Provinsi Banten?

\section{TINJAUAN TEORI DAN PENELITIAN TERDAHULU}

\section{A. Tinjauan Teori}

1. Kualitas Pelayanan

"Angelova and Zekiri (2011 : 238), menyatakan bahwa: "Perceived service quality is a global judgedment, or attitude, relation to the superiority of the service, whereas satisfaction is related to a specific transaction". Abedniya, Zaeim, Hakimi (2011 : 606), menyatakan bahwa : "Perceive service quality is a scale for firm to meansure how much they were successful to cover their customer purpose. Customer assigned their perception of service that firm's service for their customer according their experience of the process of firm's service delivered. On the other hands, marketers believe that perceive service quality compose of two main concept including customer expectation and customer perception". Irfan dan ljaz (2011 : 5), mendefinisikan bahwa : "Service quality is the judgendment and consequences of consumers after making comprizon of expectation with the perception of actual service delivered to them by the service organizatio"n.

\section{Customer Relationship Management}

Taleghani et, al (2011 : 79), kualitas relasi adalah "relationship quality defines from focusing on transaction on Building long term, profitable relationship, companies focus on their most profitable customers, Products and channels". Kotler dan Armstrong (2013 : 34)"Customer relationship management (CRM) is the process of carefully managing detailed information about individual customers and all customer "touch points" to maximize customer loyalty". Talet, Shawosh, and Al-Saeed (2011 : 3) mengatakan bahwa : "Customer relationship is defined as a process / application that permits organizations togather and analyze customer data rapidly while seeking to improve customer loyalty via targeted products and services". 


\section{Kepercayaan Konsumen}

Al-Hawari (2011: 47) mendefinisikan kepercayaan adalah sebagai berikut: "Trus is a key factor in establishing a long term relationship between organization and their custome"r. Li Maohua (2010), mengatakan bahwa "view of the long-term strategy that emphasizes intersction of side and a humanitarian, this focus the importance of relationships with relational build trus with customers". Mahdi (2011 : 55), mengatakan bahwa "trust is the customer's confidence in integrity and effectiveness in profiding better service". Henderson at. all (2011), menjelaskan bahwa "to gain consumer confidence company should do in such a way that shows customers that the company has value if it was made a partner".

\section{B. Penelitian Terdahulu}

Penelitian terdahulu diperlukan dalam suatu penelitian untuk mengetahui apakah judul dalam penelitian ini ada yang sama atau tidak, dari sisi variabel yang dianalisis tentunya ada kesamaan dan perbedaan. Adapun Kajian terdahulu yang menjadi referensi terkait dengan penelitian ini disampaikan pada tabel di bawah ini :

Tabel 2.1. : Penelitian Terdahulu

\begin{tabular}{|c|c|c|c|c|c|}
\hline No. & $\begin{array}{l}\text { Peneliti, } \\
\text { Tahun }\end{array}$ & Judul Penelitian & $\begin{array}{l}\text { Kesamaan } \\
\text { Variabel }\end{array}$ & $\begin{array}{c}\text { Perbedaan } \\
\text { Variabel }\end{array}$ & Hasil Penelitian \\
\hline 1 & $\begin{array}{c}\text { Cerri Shpetim } \\
\text { (2012) } \\
\text { Journal of } \\
\text { Competitive } \\
\text { ness, } \\
\text { Vol. 4, Issue 4, } \\
\text { pp. 16-35, } \\
\text { December } \\
\text { 2012, ISSN } \\
\text { 1804-1728 }\end{array}$ & $\begin{array}{l}\text { "Exploring the } \\
\text { Relationships among } \\
\text { Service Quality, } \\
\text { Satisfaction, Trust } \\
\text { and Store Loyalty } \\
\text { among } \\
\text { Retail Customers" }\end{array}$ & $\begin{array}{l}\text { Relationships } \\
\text { Service } \\
\text { Quality } \\
\text { Trust }\end{array}$ & \begin{tabular}{|l|} 
Satisfaction \\
Store Loyalty
\end{tabular} & $\begin{array}{l}\text { Secara fundamental } \\
\text { hubungan pelanggan } \\
\text { dan kualitas } \\
\text { pelayanan } \\
\text { berpengaruh signifikan } \\
\text { terhadap kepercayaan } \\
\text { dan loyalitas } \\
\text { pelanggan }\end{array}$ \\
\hline 2 & 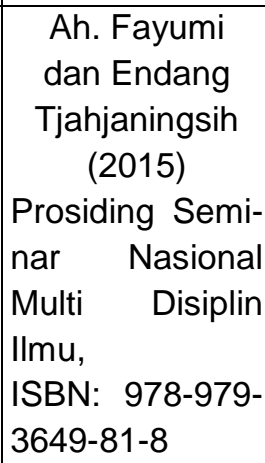 & $\begin{array}{l}\text { "Pengaruh Citra } \\
\text { Perusahaan Dan } \\
\text { Kepuasan Terhadap } \\
\text { Kepercayaan Dan } \\
\text { Dampaknya Pada } \\
\text { Loyalitas" }\end{array}$ & \begin{tabular}{|l} 
Citra \\
Perusahaan \\
Kepercayaan
\end{tabular} & $\begin{array}{l}\text { Kepuasan } \\
\text { Loyalitas }\end{array}$ & \begin{tabular}{ll}
\multicolumn{3}{|l}{ Citra perusahaan dan } \\
kepuasan r \\
berpengaruh positif \\
dan signifikan \\
terhadap kepercayaan \\
secara langsung serta \\
berpengaruh tidak \\
langsung terhadap \\
loyalitas pelanggan
\end{tabular} \\
\hline 3 & $\begin{array}{c}\text { Farzana } \\
\text { Quoquab, et al. } \\
(2013) \\
\text { American Jour- } \\
\text { nal of Econo- } \\
\text { mics } 2013 \text {, } \\
3(5 \mathrm{C}): 177-183\end{array}$ & $\begin{array}{l}\text { "A Structural Look at } \\
\text { Service Loyalty:Role } \\
\text { of Service } \\
\text { Quality, Corporate } \\
\text { Image, and Trust" }\end{array}$ & \begin{tabular}{|l|} 
Service \\
Quality \\
Corporate \\
Image \\
Trust \\
Kemitraan
\end{tabular} & & $\begin{array}{l}\text { Hasil } \\
\text { membuktikan bahwa } \\
\text { loyalitas dibangun } \\
\text { oleh kepercayaan } \\
\text { yang dipengaruhi oleh } \\
\text { citra, kemitraan dan } \\
\text { kualitas pelayanan }\end{array}$ \\
\hline
\end{tabular}


JURNAL ILMIAH ILMU MANAJEMEN

E-ISSN 2598-4950

\begin{tabular}{|c|c|c|c|c|c|}
\hline No. & $\begin{array}{c}\text { Peneliti, } \\
\text { Tahun }\end{array}$ & Judul Penelitian & $\begin{array}{c}\text { Kesamaan } \\
\text { Variabel }\end{array}$ & $\begin{array}{c}\text { Perbedaan } \\
\text { Variabel }\end{array}$ & Hasil Penelitian \\
\hline 4 & $\begin{array}{l}\text { Mohamad } \\
\text { Dimyati } \\
(2011) \\
\text { Journal of } \\
\text { Economics, } \\
\text { Business and } \\
\text { Accountancy } \\
\text { Ventura Volume } \\
\text { 14, No. 3, Dec. } \\
\text { 2011, pages } \\
\text { 225-238 }\end{array}$ & $\begin{array}{l}\text { "Theoretical Testing } \\
\text { On Service Quality } \\
\text { And Product } \\
\text { Innovation Of Small- } \\
\text { Micro Credit Banks" }\end{array}$ & \begin{tabular}{|l} 
Kualitas \\
Pelayanan \\
Kepercayaan \\
Nasabah
\end{tabular} & $\begin{array}{l}\text { Kepuasan } \\
\text { Inovasi } \\
\text { Loyalitas } \\
\text { Nasabah }\end{array}$ & $\begin{array}{lr}\text { Hasil } & \text { penelitian } \\
\text { membuktikan bahwa } & \text { kualitas pelayanan, } \\
\text { kepuasan dan inovasi } & \text { produk berpengaruh } \\
\text { terhadap } & \text { kepercayaan } \\
\text { nasabah, } & \text { namun tidak } \\
\text { semuarrariabel } \\
\text { eksogen } & \text { berpengaruh } \\
\text { signifikan terhadap } \\
\text { variabel loyalitas. }\end{array}$ \\
\hline 5 & $\begin{array}{c}\text { Osrita Hapsara } \\
\text { (2012) } \\
\text { Disertasi UPI- } \\
\text { Y.A.I }\end{array}$ & $\begin{array}{l}\text { "Pengaruh kualitas } \\
\text { pelayanan yang } \\
\text { dirasakan dan } \\
\text { kemitraan terhadap } \\
\text { nilai nasabah serta } \\
\text { implikasinya pada } \\
\text { kepercayaan } \\
\text { nasabah jasa } \\
\text { simpanan Bank } \\
\text { Jambi" }\end{array}$ & $\begin{array}{l}\text { Kualitas } \\
\text { pelayanan } \\
\text { Kemitraan } \\
\text { (CRM), } \\
\text { Kepercayaan }\end{array}$ & Nilai nasabah & $\begin{array}{l}\text { Secara keseluruhan } \\
\text { variabel eksogen ber- } \\
\text { pengaruh terhadap va- } \\
\text { riabel endogen baik } \\
\text { dalam struktur I } \\
\text { maupun struktur II. } \\
\text { Namun Variabel kemi- } \\
\text { traan memiliki penga- } \\
\text { ruh yang signifikan } \\
\text { terhadap nilai dan } \\
\text { kepercayaan nasabah }\end{array}$ \\
\hline
\end{tabular}

\section{Kerangka Pemikiran}

Kerangka pikir adalah merupakan alur penelitian agar mudah dipahami, sehingga dapat digambarkan kerangka pikir sebagai berikut :

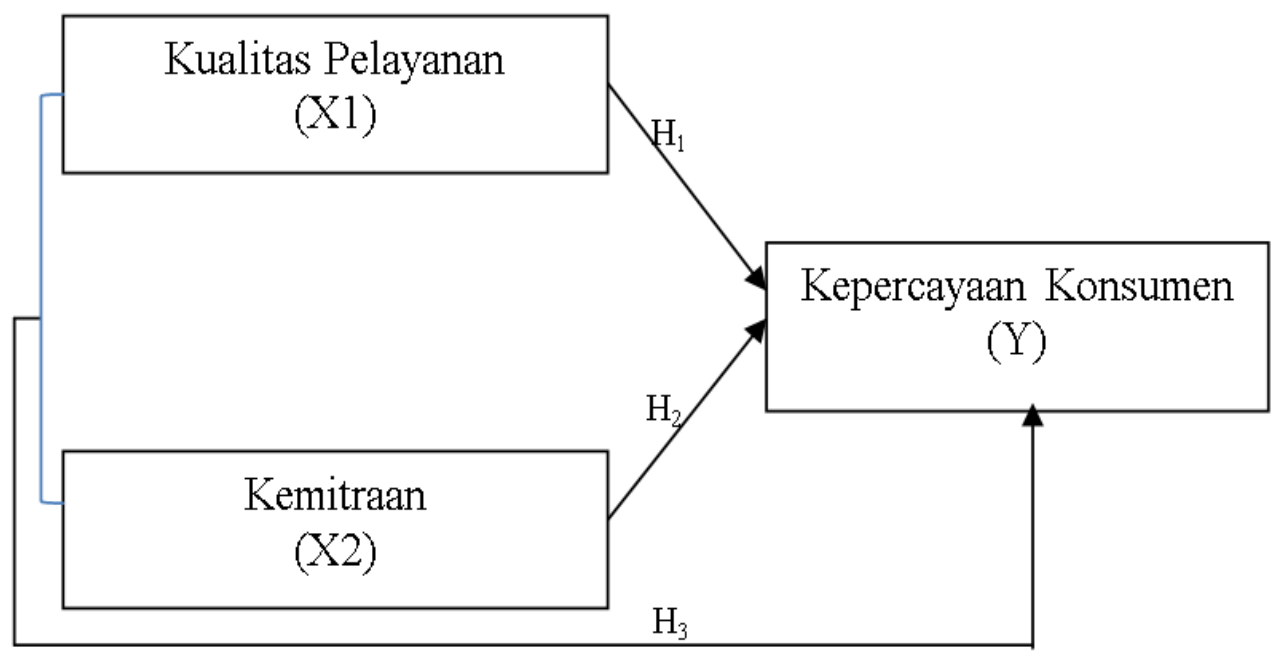

Gambar 1 : Kerangka Pikir 


\section{Hipotesis Penelitian}

Berdasarkan paparan di atas, maka dapat diajukan hipotesis penelitian sebagai berikut:

$\mathrm{H}_{1}$ : Terdapat pengaruh kualitas pelayanan terhadap kepercayaan konsumen dalam menggunakanJasa Konsultan Lingkungan di Provinsi Banten.

$\mathrm{H}_{2}$ : Terdapat pengaruh kemitraan terhadap kepercayaan konsumen dalam menggunakanJasa Konsultan Lingkungan di Provinsi Banten.

$\mathrm{H}_{3}$ : Terdapat pengaruh kualitas pelayanan dan secara bersama-sama terhadap kepercayaan konsumen dalam menggunakan Jasa Konsultan Lingkungan di Provinsi Banten.

\section{METODE PENELITIAN}

A. Populasi dan Sampel

Populasi dalam penelitian ini adalah perusahaan konstruksi yang mengurus izin lingkungan ke Badan Lingkungan Hidup Provinsi Banten yang berjumlah 1497 perusahaan. Sedangkan objek analisis dalam penelitian ini adalah perusahaan jasa konsultan lingkungan di Provinsi Banten yang berjumlah 12 perusahaan.

Pedoman penentuan jumlah sampel dalam penelitian ini mengacu pada syarat jumlah sampel minimum. Dalam penelitian ini, teknik penentuan jumlah sampel menggunakan rumus dari Rao Purba dalam Ghozali (2016:108) yaitu sebagai berikut :

Keterangan :

$$
n=\frac{\mathrm{Z}^{2}}{4(\text { Moe })^{2}}
$$

$\mathrm{n}=$ Ukuran Sampel

$\mathrm{Z}=1,96$ score pada tingkat signifikansi tertentu (derajat keyakinan ditentukan 95\%)

Moe $=$ Margin of error, tingkat kesalahan maksimum adalah $10 \%$.

Dengan menggunakan rumus di atas, maka diperoleh perhitungan sebagai berikut :

$$
n=\frac{(1,96)^{2}}{4(10 \%)^{2}}=96,04 \sim \text { dibulatkan } 100
$$

\section{B. Metode Analisis Data}

Metode analisis yang digunakan adalah statistik deskriptif adalah "statistik yang digunakan untuk menganalisis data dengan cara menjelaskan gambaran data yang telah terkumpul sebagaimana adanya atau aslinya tanpa bermaksud untuk membuat kesimpulan yang berlaku secara umum" (Sugiyono, 2012:147). Adapun metode analisis deskriptif yang digunakan adalah metode rata-rata kuesioner.

Tabel 1 : Skala Interval

\begin{tabular}{|c|l|c|c|}
\hline No. & \multicolumn{1}{|c|}{ Kriteria } & Disingkat & Skor Nilai \\
\hline 1. & Sangat Baik & SB & $4,20-5,00$ \\
\hline 2. & Baik & B & $3,40-4,19$ \\
\hline
\end{tabular}




\section{JURNAL ILMIAH ILMU MANAJEMEN}

\begin{tabular}{|l|l|c|c|}
\hline 3. & Cukup/Kurang Baik & CB/KB & $1,60-3,39$ \\
\hline 4. & Rendah & $\mathrm{R}$ & $1,80-2,59$ \\
\hline 5. & Sangat Rendah & SR & $1,00-1,79$ \\
\hline
\end{tabular}

Sumber : Sugiyono (2013:94)

\section{Uji Regresi Linier}

Regresi linear berganda merupakan regresi yang di dalamnya mempunyai satu variabel dependen/terikat $(Y)$ dan lebih dari satu variabel independen/bebas $(X)$. Variabel dependen adalah variabel terikat yang merupakan variabel yang dipengaruhi oleh variabel independen/bebas.

\section{Uji Koefisiensi Determinasi}

Koefisien determinasi $\left(R^{2}\right)$ adalah untuk mengetahui seberapa besar kemampuan variabel bebas menjelaskan variabel terikat. Dalam output SPSS, koefisien determinasi terletak pada tabel Model Summary ${ }^{b}$ dan tertulis Adjusted $R$ Square.Nilai $R^{2}$ sebesar 1 , berarti fluktuasi variabel dependen seluruhnya dapat dijelaskan oleh variabel independen dan tidak ada faktor lain yang menyebabkan fluktuasi variabel dependen. "Jika nilai $R^{2}$ berkisar antara 0 sampai dengan 1 , berarti semakin kuat kemampuan variabel independen dapat menjelaskan fluktuasi variabel dependen" (Ghozali, 2016:95).

\section{ANALISIS DAN PEMBAHASAN}

\section{A. Deskriptif Data}

Sebagaimana yang telah diuraikan pada bab sebelumnya, bahwa variabel penelitian yang diteliti adalah kualitas pelayanan, kemitraan dan kepercayaan konsumen.

Tabel 2 : Analisis Deskriptif Kualitas Pelayanan

\begin{tabular}{|c|c|c|c|c|}
\hline No. & & Dimensi/Indikator & Rata-rata & Kategori \\
\hline 1 & Bukti fisik & $\begin{array}{llll}\begin{array}{l}\text { Ketersediaan } \\
\text { memadai }\end{array} & \text { Tenaga } & \text { Ahli } & \text { yang } \\
\end{array}$ & 3.64 & Baik \\
\hline & & $\begin{array}{l}\text { Ketersediaan Peralatan uji kelayakan } \\
\text { lingkungan yang memadai }\end{array}$ & 3.65 & Baik \\
\hline Rat & a-rata Bukti I & isik & 3.64 & Baik \\
\hline 2 & Kehandalan & Kehandalan dalam survey & 3.74 & Baik \\
\hline & & $\begin{array}{l}\text { Kehandalan dalam merumuskan hasil } \\
\text { survey }\end{array}$ & 3.80 & Baik \\
\hline Rat & a-rata Kehan & dalan & 3.77 & Baik \\
\hline 3 & \begin{tabular}{|l|} 
Daya \\
Tanggap
\end{tabular} & $\begin{array}{l}\text { Kecepatan dalam memberikan laporan } \\
\text { data hasil uji }\end{array}$ & 3.70 & Baik \\
\hline Rat & a-rata Daya 1 & anggap & 3.70 & Baik \\
\hline 4 & Jaminan & $\begin{array}{l}\text { Jaminan atas hasil uji kelayakan } \\
\text { lingkungan }\end{array}$ & 3.90 & Baik \\
\hline
\end{tabular}


JURNAL ILMIAH ILMU MANAJEMEN

\begin{tabular}{|c|c|c|c|c|}
\hline \multirow[t]{2}{*}{ No. } & \multicolumn{2}{|r|}{ Dimensi/Indikator } & \multirow{2}{*}{\begin{tabular}{|c|} 
Rata-rata \\
3.87
\end{tabular}} & \multirow{2}{*}{$\frac{\text { Kategor }}{\text { Baik }}$} \\
\hline & & $\begin{array}{l}\text { Jaminan atas keseuaian proses uji } \\
\text { dengan prosedur yang ditetapkan }\end{array}$ & & \\
\hline \multicolumn{3}{|c|}{ Rata-rata Jaminan } & 3.89 & Baik \\
\hline \multirow[t]{2}{*}{5} & \multirow[t]{2}{*}{ Empati } & $\begin{array}{l}\text { Kesabaran dalam memberikan jasa } \\
\text { konsultasi pada para konsumen }\end{array}$ & 3.87 & Baik \\
\hline & & $\begin{array}{l}\text { Kesopanan dalam memberikan jasa } \\
\text { konsultasi pada konsumen }\end{array}$ & 4.12 & Baik \\
\hline \multicolumn{3}{|c|}{ Rata-rata Empati } & 4.00 & Baik \\
\hline \multicolumn{3}{|c|}{ Rata-rata Kualitas Pelayanan } & 3.81 & Baik \\
\hline
\end{tabular}

Sumber : Olah data, 2018

Tabel 3 : Analisis Deskriptif Kemitraan

\begin{tabular}{|c|c|c|c|c|}
\hline No & \multicolumn{1}{|c|}{ Dimensi/Indikator } & Rata-rata & Kategori \\
\hline 1 & Berkelanjutan & $\begin{array}{l}\text { Tingkat daya tarik pada program } \\
\text { kerja sama }\end{array}$ & 3.66 & Baik \\
\hline $\begin{array}{l}\text { Tingkat daya tarik pada program } \\
\text { promosi }\end{array}$ & 3.70 & Baik \\
$\begin{array}{l}\text { Tingkat daya tarik pada fasilitas } \\
\text { khusus }\end{array}$ & 3.49 & Baik \\
\hline \multicolumn{2}{|l|}{ Rata-rata Berkelanjutan } & 3.62 & Baik \\
\hline $\begin{array}{l}\text { Individual } \\
\text { Marketing }\end{array}$ & $\begin{array}{l}\text { Tingkat kecermatan dalam pelayanan } \\
\text { Tingkat penanganan keluhan }\end{array}$ & 3.81 & Baik \\
\hline Rata-rata Individual Marketing pelayanan & 3.93 & Baik \\
\hline 3 & $\begin{array}{l}\text { Jaringan } \\
\text { Pemasaran }\end{array}$ & $\begin{array}{l}\text { Memiliki kemitraan yang luas } \\
\text { handal jaringan informasi yang }\end{array}$ & 3.82 & Baik \\
\hline
\end{tabular}

Sumber : Olah data, 2018

Tabel 4 : Analisis Deskriptif Kepercayaan Konsumen

\begin{tabular}{|c|c|c|c|c|}
\hline No. & \multicolumn{2}{|c|}{ Dimensi/Indikator } & Rata-rata & Kategori \\
\hline \multirow[t]{3}{*}{1} & \multirow[t]{3}{*}{ Kejujuran } & $\begin{array}{l}\text { Jujur dalam menyampaikan } \\
\text { informasi }\end{array}$ & 4.05 & Baik \\
\hline & & $\begin{array}{l}\text { Terbuka dalam perhitungan } \\
\text { biaya }\end{array}$ & 3.67 & Baik \\
\hline & & $\begin{array}{l}\text { Terbuka dalam penyampaian } \\
\text { proses AMDAL }\end{array}$ & 3.71 & Baik \\
\hline \multicolumn{3}{|c|}{ Rata-rata Kejujuran } & 3.81 & Baik \\
\hline \multirow[t]{2}{*}{2} & \multirow[t]{2}{*}{ Keadilan } & Kesamaan pelayanan & 3.80 & Baik \\
\hline & & Prioritas pekerjaan & 3.90 & Baik \\
\hline \multicolumn{3}{|c|}{ Rata-rata Keadilan } & 3.85 & Baik \\
\hline
\end{tabular}


JURNAL ILMIAH ILMU MANAJEMEN

\begin{tabular}{|c|c|c|c|c|}
\hline No. & \multicolumn{2}{|c|}{ Dimensi/Indikator } & Rata-rata & Kategori \\
\hline \multirow[t]{3}{*}{3} & \multirow[t]{3}{*}{ Kehandalan } & Ketepatan waktu & 3.53 & Baik \\
\hline & & $\begin{array}{l}\text { Cepat dalam menyelesaikan } \\
\text { masalah }\end{array}$ & 3.50 & Baik \\
\hline & & $\begin{array}{l}\text { Mampu memberikan solusi } \\
\text { atas masalah }\end{array}$ & 3.85 & Baik \\
\hline \multicolumn{3}{|c|}{ Rata-rata Kehandalan } & 3.63 & Baik \\
\hline \multicolumn{3}{|c|}{ Rata-rata Kepercayaan Konsumen } & 3.75 & Baik \\
\hline
\end{tabular}

Sumber : Olah data, 2018

\section{B. Uji Hipotesis}

Tabel 5 : Uji Parsial (Uji t)

Coefficients $^{\mathrm{a}}$

\begin{tabular}{|c|c|c|c|c|c|}
\hline \multirow[b]{2}{*}{ Model } & \multicolumn{2}{|c|}{ Unstandardized Coefficients } & \multirow{2}{*}{$\frac{\text { Standardized Coefficients }}{\text { Beta }}$} & \multirow[b]{2}{*}{$\mathrm{t}$} & \multirow[b]{2}{*}{ Sig. } \\
\hline & B & Std. Error & & & \\
\hline 1 (Constant) & 2.604 & 2.435 & & 1.070 & .28 \\
\hline Kualitas Pelayanan & .388 & .110 & .388 & 3.544 & | \\
\hline Kemitraan & .467 & .116 & .440 & 4.020 & .000 \\
\hline
\end{tabular}

a. Dependent Variable: Kepercayaan

Sumber : Hasil Olah Data SPSS 22, 2018

Tabel 6 : Uji Simultan (Uji F) ANOVA $^{b}$

\begin{tabular}{|c|c|c|c|c|c|c|}
\hline \multicolumn{2}{|c|}{ Model } & Sum of Squares & $d f$ & Mean Square & $\mathrm{F}$ & Sig. \\
\hline 1 & Regression & 1081.997 & 2 & 540.999 & 65.362 & $.000^{\mathrm{a}}$ \\
\hline & Residual & 686.991 & 83 & 8.277 & & \\
\hline & Total & 1768.988 & 85 & & & \\
\hline
\end{tabular}

a. Predictors: (Constant), Kemitraan, Kualitas Pelayanan

b. Dependent Variable: Kepercayaan

Sumber: Hasil Olah Data SPSS 22, 2018

Tabel 7 : Uji Koefisien Determinasi

Model Summary ${ }^{\mathrm{b}}$

\begin{tabular}{|l|r|r|r|r|}
\hline Model & \multicolumn{1}{|c|}{$\mathrm{R}$} & \multicolumn{1}{|c|}{ R Square } & Adjusted R Square & Std. Error of the Estimate \\
\hline 1 & $.782^{\mathrm{a}}$ & .612 & .602 & 2.877 \\
\hline
\end{tabular}

a. Predictors: (Constant), Kemitraan, Kualitas Pelayanan

b. Dependent Variable: Kepercayaan

Sumber : Hasil Olah Data SPSS 22, 2018

Berdasarkan hasil olah data regresi linear berganda di atas, maka dapat dikemukakan dua hal. Pertama persamaan regresi, yaitu $Y=2.604+0.388 X_{1}+$ 
JURNAL ILMIAH ILMU MANAJEMEN

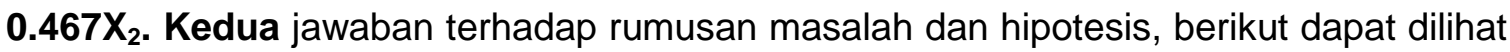
pada tabel di bawah ini.

Tabel 8 : Uji Statistik Regresi Linear Berganda

\begin{tabular}{|l|l|c|c|c|}
\hline \multicolumn{2}{|c|}{ Regresi Linear Berganda } & \multirow{2}{*}{ Koefisien Regresi } & $\boldsymbol{t}_{\text {hitung }} / \boldsymbol{F}_{\text {hitung }}$ & Hasil Uji \\
\hline \multirow{2}{*}{ Variabel Dependen } & Variabel Independen & & & \\
\hline \multirow{2}{*}{$\begin{array}{l}\text { Kepercayaan } \\
\text { Konsumen }\end{array}$} & Kualitas pelayanan & 0.388 & 3.544 & Signifikan \\
\cline { 2 - 5 } & Kemitraan & 0.467 & 4.02 & Signifikan \\
\cline { 2 - 5 } & $\begin{array}{l}\text { Kualitas Pelayanan } \\
\text { dan Kemitraan }\end{array}$ & $\mathrm{R}^{2}=0.602$ & 65.362 & Signifikan \\
\hline
\end{tabular}

Sumber: Hasil Olah Data SPSS 22, 2018

$\left[\mathrm{t}_{\text {tabel }}=1.984\right]\left[\mathrm{F}_{\text {tabel }}=3.09\right]$

Dalam penelitian ini ada 3 (tiga) hipotesis yang diuji $(\mathrm{H} 1, \mathrm{H} 2$, dan $\mathrm{H} 3)$, dari 3 hipotesis tersebut berdasarkan hasil pengujian tabel di atas, maka diperoleh kesimpulan bahwa hipotesis $\mathrm{H} 1, \mathrm{H} 2$, dan $\mathrm{H} 3$ diterima. Hasil selengkapnya dari pengujian masingmasing hipotesis dapat dilihat pada tabel di bawah ini.

Tabel 9 : Hasil Pengujian Hipotesis

\begin{tabular}{|c|l|c|}
\hline Hipotesis & \multicolumn{1}{|c|}{ Deskripsi } & Kesimpulan \\
\hline H1 & $\begin{array}{l}\text { Kualitas pelayanan berpengaruh signifikan terhadap } \\
\text { kepercayaan konsumen }\end{array}$ & Diterima \\
\hline H2 & $\begin{array}{l}\text { Kemitraan berpengaruh signifikan terhadap } \\
\text { kepercayaan konsumen }\end{array}$ & Diterima \\
\hline H3 & $\begin{array}{l}\text { Kualitas pelayanan dan Kemitraan berpengaruh } \\
\text { signifikan terhadap kepercayaan konsumen }\end{array}$ & Diterima \\
\hline
\end{tabular}

Sumber : Hasil Olah Data SPSS 22, 2018

Hasil uji hipotesis di atas, secara rinci dapat dijelaskan sebagai berikut.

1. Pengaruh kualitas pelayanan terhadap kepercayaan konsumen

Hasil analisis regresi mandiri menunjukkan bahwa kualitas pelayanan berkontribusi signifikan terhadap kepercayaan konsumen dengan nilai prediksi (regresi) sebesar 0.388 , nilai $t_{\text {hitung }}$ sebesar 3.544 dan nilai signifikansi sebesar 0.001, maka dapat disimpulkan Ha diterima dan HO ditolak. Dengan penafsiran bahwa setiap peningkatan/penambahan (karena tanda + ) satu skor dari variabel kualitas pelayanan maka diprediksikan akan meningkatkan variabel kepercayaan sebesar 0.388 .

Penjelasan yang dapat dikemukakan atas hasil penelitian di atas adalah, Pertama, temuan ini telah mengonfirmasi teori bahwa kualitas pelayanan yang baik dapat meningkatkan kepercayaan konsumen, begitu pula hasil penelitian terdahulu juga mengemukakan hal yang sama (Cerri Shpetim, 2012). Kedua, temuan ini mengonfirmasi kondisi nyata yang dialami oleh para konsumen, dalam hal ini 
perusahaan-perusahaan yang pernah menggunakan jasa konsultan AMDAL di Provinsi Banten mengenai pelayanan-pelayanan AMDAL yang berdampak pada kepercayaan perusahaan-perusahaan itu sendiri. Sebagaimana hasil analisis deskriptif menunjukkan bahwa pelayanan yang terbangun dari jasa konsultan AMDAL adalah empati, di mana para konsultan AMDAL memiliki sikap sabar dan sopan terhadap para klien, baik pada saat konsultasi maupun pada saat pelaksanaan pekerjaan. Bahkan konsultan AMDAL di Provinsi Banten tetap menunjukkan sikap sabar dan sopannya pada saat laporan akhir atau pasca proyek AMDAL. Kondisi nyata inilah yang membuat kepercayaan konsumen terbangun, yaitu dalam hal keadilan. Keadilan yang dimaksud adalah tentang sikap para konsultan AMDAL yang tidak membeda-bedakan pelayanan terhadap para kliennya, bahkan mereka tetap konsisten dengan prioritas pekerjaan yang telah disepakati.

Ketiga, berdasarkan kondisi di atas secara statistik memberikan saran atau rekomendasi yang bersifat peluang. Jika konsultan AMDAL di Provinsi Banten dapat terus meningkatkan keunggulan pelayanan dan terus memperbaiki kekurangan pelayanan yang ada saat ini maka di masa mendatang akan dapat meningkatkan kepercayaan konsumen sebesar 0,388.

Keempat, hal yang menarik dari temuan ini adalah tentang kelemahan kualitas pelayanan yang diberikan oleh konsultan AMDAL. Hasil analisis deskriptif menunjukkan jika ketersediaan tenaga ahli dan ketersediaan peralatan uji kelayakan lingkungan adalah kekurangan pada pelayanan konsultan AMDAL provinsi Banten, sehingga kepercayaan konsumen yang terbangun adalah keadilan, sejatinya kepercayaan yang terbangun adalah kehandalan yakni ketepatan waktu mengerjakan proyek, menyelesaikan masalah dengan cepat serta mampu menampilkan solusi dari pemasalahan yang ada. Karena yang lebih dibutuhkan dalam pengurusan AMDAL adalah kehandalan, di samping memperhatikan aspek keadilan.

\section{Pengaruh kemitraan terhadap kepercayaan konsumen}

Hasil analisis regresi mandiri menunjukkan bahwa kemitraan berkontribusi signifikan terhadap kepercayaan konsumen dengan nilai prediksi (regresi) sebesar 0.467 , nilai $t_{\text {hitung }}$ sebesar 4.020 dan nilai signifikansi sebesar 0.000 , maka dapat disimpulkan $\mathrm{Ha}$ diterima dan $\mathrm{HO}$ ditolak. Dengan penafsiran bahwa setiap peningkatan/penambahan (karena tanda + ) satu skor dari variabel kemitraan maka diprediksikan akan meningkatkan variabel kepercayaan sebesar 0.467.

Penjelasan yang dapat dikemukakan atas hasil penelitian di atas adalah, Pertama, temuan ini telah mengonfirmasi teori bahwa kemitraan yang baik dapat meningkatkan kepercayaan konsumen, begitu pula hasil penelitian terdahulu juga mengemukakan hal yang sama (Farzana Quoquab, et al, 2013). Kedua, temuan ini mengonfirmasi kondisi nyata yang dialami oleh para konsumen, dalam hal ini perusahaan-perusahaan yang pernah menggunakan jasa konsultan AMDAL di Provinsi Banten mengenai jaringan pemasaran konsultan AMDAL yang berdampak pada kepercayaan perusahaan-perusahaan itu sendiri. Sebagaimana hasil analisis deskriptif menunjukkan bahwa kemitraan yang terbangun dari jasa konsultan AMDAL adalah jaringan pemasaran, di mana para konsultan AMDAL memiliki 
jaringan informasi yang handal dengan BLHD di Kota, Kabupaten dan Provinsi. Bahkan ada sebagian konsultan AMDAL yang memiliki jaringan di Kementrian Lingkungan Hidup, sehingga proses pengerjaan AMDAL lebih mudah dan dapat dipastikan berjalan dengan lancar. Kondisi nyata inilah yang membuat kepercayaan konsumen terbangun, yaitu dalam hal keadilan. Keadilan yang dimaksud adalah tentang sikap para konsultan AMDAL yang tidak membeda-bedakan pelayanan terhadap para kliennya, bahkan mereka tetap konsisten dengan prioritas pekerjaan yang telah disepakati, dengan demikian kepercayaan konsumen meningkat.

Ketiga, berdasarkan kondisi di atas secara statistik memberikan saran atau rekomendasi yang bersifat prediksi. Jika konsultan AMDAL di Provinsi Banten dapat terus meningkatkan keunggulan kemitraan dan terus memperbaiki kekurangan kemitraan yang ada saat ini maka di masa-masa mendatang akan dapat meningkatkan kepercayaan konsumen sebesar 0,467.

Keempat, hal yang menarik dari temuan ini adalah tentang kelemahan kemitraan yang dimiliki oleh konsultan AMDAL. Hasil analisis deskriptif menunjukkan minimnya fasilitas AMDAL adalah kekurangan pada kemitraan konsultan AMDAL provinsi Banten, sehingga kepercayaan konsumen yang terbangun adalah keadilan, sejatinya kepercayaan yang terbangun adalah kehandalan yakni ketepatan waktu mengerjakan proyek, cepat dalam menyelesaikan masalah dan mampu memberikan solusi efektif dalam memecahkan masalah. Karena yang lebih dibutuhkan dalam pengurusan AMDAL adalah kehandalan, di samping memperhatikan aspek keadilan.

\section{Pengaruh kualitas pelayanan dan kemitraan terhadap kepercayaan konsumen}

Hasil analisis regresi simultan menunjukkan bahwa kualitas pelayanan dan kemitraan secara bersama-sama berkontribusi signifikan terhadap kepercayaan konsumen dengan nilai kontribusi sebesar 0.602 , nilai $F_{\text {hitung }}$ sebesar 65.362 dan nilai signifikansi sebesar 0.000 , maka dapat disimpulkan $\mathrm{Ha}$ diterima dan $\mathrm{HO}$ ditolak. Dengan penafsiran bahwa setiap peningkatan/penambahan satu skor dari variabel kualitas pelayanan dan kemitraan maka diprediksikan akan memberikan kontribusi terhadap peningkatan variabel kepercayaan sebesar 0.602 atau $60.2 \%$, sedangkan sisanya sebesar 0.398 atau $39,8 \%$ dijelaskan oleh variabel lain di luar penelitian ini.

Temuan ini mengonfirmasi teori bahwa kualitas pelayanan yang baik dan adanya "jaringan pemasaran yang luas mampu meningkatkan kepercayaan konsumen". Sebagaimana hasil penelitian yang dilakukan oleh Cerri Shpetim (2012), Ah. Fayumi dan Endang Tjahjaningsih (2015), Farzana Quoquab, et al (2013), Mohamad Dimyati (2011), dan Osrita Hapsara (2012) menyatakan terdapat pengaruh kualitas pelayanan dan kemitraan terhadap kepercayaan konsumen.

Secara empiris temuan di atas membuktikan fakta lapangan atau keadaan yang sesungguhnya mengenai kepercayaan konsumen yang diukur berdasarkan kualitas pelayanan dan kemitraan. Hasil analisis deskriptif menunjukkan bahwa pelayanan konsultan AMDAL sudah baik dalam hal empati terutama mengenai sikap kesopanan dengan rata-rata skor 4.12 masuk pada kategori baik, sehingga 
kepercayaan yang terbangun adalah mengenai sikap keadilan konsultan AMDAL. Begitu pula kemitraan konsultan AMDAL yang terbangun baik adalah jaringan pemasaran terutama kehandalan informasi dengan pihak BLHD kota, daerah, propinsi maupun kementrian.

Berdasarkan kondisi di atas, maka secara statistik memberikan saran atau rekomendasi bahwa kualitas pelayanan dan kemitraan yang dibangun secara bersama-sama akan dapat memberikan kontribusi terhadap peningkatan kepercayaan konsumen yaitu sebesar $60,2 \%$. Angka ini memiliki pengertian bahwa kondisi saat ini jika terus ditingkatkan mengenai kualitas pelayanan dan kemitraan serta dilakukan perbaikan-perbaikan mengenai kekurangan-kekurangan yang ada maka di masa-masa mendatang mampu meningkatkan kepercayaan konsumen.

\section{KESIMPULAN DAN SARAN}

A. Kesimpulan

1. Kualitas pelayanan berkontribusi signifikan terhadap kepercayaan konsumen dalam menggunakanJasa Konsultan Lingkungan di Provinsi Banten dengan koefisien regresi sebesar 0,388.

2. Kemitraan berkontribusi signifikan terhadap kepercayaan konsumen dalam menggunakanJasa Konsultan Lingkungan di Provinsi Banten dengan koefisien regresi sebesar 0,467.

3. Kualitas pelayanan dan kemitraan secara bersama-sama berkontribusi signifikan terhadap kepercayaan konsumen dalam menggunakanJasa Konsultan Lingkungan di Provinsi Banten dengan koefisien determinasi sebesar 0,602.

\section{B. Saran}

1. Untuk meningkatkan kualitas pelayanan, maka pihak konsultan lingkungan hidup dapat meningkatkan ketersediaan tenaga ahli.

2. Untuk meningkatkan kemitraan, maka pihak konsultan lingkungan hidup untuk menyediakan fasilitas yang memadai, seperti alat uji atau laboratorium.

3. Untuk meningkatkan kepercayaan konsumen, maka pihak konsultan lingkungan hidup dapat meningkatkan kemampuannya dalam menyelesaikan masalah secara cepat atau tepat waktu.

\section{DAFTAR PUSTAKA}

Ah. Fayumidan Endang Tjahjaningsih, (2015), Pengaruh Citra Perusahaan Dan Kepuasan Terhadap Kepercayaan Dan Dampaknya Pada Loyalitas, Prosiding Seminar Nasional Multi Disiplin IImu, ISBN: 978-979-3649-81-8.

Al-Hawari, Mohammad Ahmad, (2011), Automated service quality a predictor of customers commitment. A practical study within the UAE retail banking context. Journal of Management, Marketing and Publiuc Adminstration Departement Business Faculty, University of Sharjah, Sharjah, United Arab Emirates (Februari 2011) $246: 366$. 
Angelova, B dan Jusuf Zekiri, (2011), Measuring Customer Satisfaction with Service Quality Using American Customer Satisfaction Model (ACSI Model), International Journal of Academic Research in Business and Social Sciences October 2011, Vol. 1, No. 3 ISSN: 2222-6990 232.

Abedniya, Abed, Majid Nokhbeh Zaeim, Bardia Yousef Hakimi, (2011), Investigation the Relationship between Customer's Perceived Service Quality and Satisfaction : Islamic Book in Malaysia, Europian Journal of Social Science. Vol. 21. Number 4.

Cerri Shpetim, (2012), Exploring the Relationships among Service Quality, Satisfaction, Trust and Store Loyalty among Retail Customers, Journal of Competitiveness, Vol. 4, Issue 4, pp. 16-35, December 2012, ISSN 1804-1728

Farzana Quoquab, et al., (2013), A Structural Look at Service Loyalty:Role of Service Quality, Corporate Image, and Trust,American Journal of Economics 2013, 3(5C): 177-183.

Ghozali, Imam.(2012). Analisis SEM dengan Amos, Semarang. BPPE.

Henderson, Conor M, Joshua T, Beck, and Robert W Palmatier, (2011), Review of The Theoretical Underpinnings of Loyality Programs. Science Ddirect, Journal of Customer Psychology. JCPS - 00219

Irfan, ljaz, (2011), Comparison of service quality between private and public hospitals: Empirical Evidences from Pakistan, IJTM (VII) : 1-22.

Kotler, Philip and Gary Amstrong. (2012). Prinsip-prinsip Pemasaran. Edisi 13. Jilid 1. Alih bahasa, Bob Sabran. Jakarta. Erlangga.

Li Maohua, (2010), The Costumer Value Strategy in the Competitiveness of Companies, International Journal Of Business and Management. Vol.4, No.2.

Mahdi, Mohamed, Osman, Shereif, (2011), Males and females views on trust in electronic banking services in Saudi banks, Global Business and Social Science Research. Paper No.604.

Mohamad Dimyati, (2011), Theoretical Testing On Service Quality And Product Innovation Of Small-Micro Credit Banks, Journal of Economics, Business and Accountancy Ventura Volume 14, No. 3, December 2011, pages 225 - 238.

Osrita Hapsara (2012), Pengaruh kualitas pelayanan yang dirasakan dan kemitraan terhadap nilai nasabah serta implikasinya pada kepercayaan nasabah jasa simpanan Bank Jambi, Disertasi UPI-Y.A.I.

Sugiyono. (2012). Metode Penelitian Bisnis. Bandung. Alfabeta.

Taleghani et al, (2011), The Investigation and Analysis Impact of brand Dimensions on Services Quality and Customers Satisfaction in New Entreprises of Iran, volume 1, No. 6.

Talet Amine Nehari, Shawosh Mazen Harbi and Saeed A. Al-Saeed, (2011), The Perception of Customer RelationshipManagement Adoption Case of Mobile Companies in Saudi Arabia, Journal of Mobile Technologies, Knowledge \& Society. Vol. 2011 (2011), Article ID 940658, 13 pages. 